\title{
A ilegalidade de bens e direitos no sistema capitalista: uma análise a partir do pensamento de Michael Foucault
}

\author{
Márcio Bonini Notari ${ }^{1}$
}

1 Possui graduação em Direito pela Universidade Católica de Pelotas (2008). Especialização em Direito e Processo do Trabalho pela Anhanguera RS ( 2010) e Mestrado em Direito pela Universidade de Santa Cruz do Sul (2015). Doutorando em Direitos Fundamentais pela Universidade do Oeste de Santa Catarina, Campus Chapecó.

E-mail: marciobnotari@gmail.com Orcid: http://orcid.org/0000-0003-1458-7386

RESUMO: Michel Foucault (1926-1984) embora não tenha sistematizado uma Teoria ou Filosofia do Direito em sentido estrito e, mesmo não sendo da área jurídica, construiu suas propostas em diversas obras, as quais acabam tecendo críticas e considerações acerca do Direito Penal e do Sistema de Justiça Criminal, a partir do modelo panóptico e das novas formas de punição no ambito do cárcere, envolvendo a transição do modelo feudal para o sistema capitalista de produção. Nesse sentido que se pode perguntar: qual a concepção foucaultiana em relação às ilegalidades nesse novo modelo punitivo? $\mathrm{Na}$ hipótese a ser desenvolvida, Foucault parte de uma crítica ao formato das ilegalidades de bens e as ilegalidades de direitos, repensando o aparato judicial e seu estatuto jurídico o qual tem por finalidade "não a igualdade de todos perante a lei", mas proteção da propriedade dos bens e, por consequência, a repressão ao ilegalismo popular; por outro lado, a permissão para a prática de ilícitos pelos detentores dos meios produtivos.

Palavras chave: Ilegalidade, bens, direito, capitalismo.

ABSTRACT: Michel Foucault (1926-1984) although he did not systematize a Theory or Philosophy of Law in the strict sense and, even though it is not in the legal area, he built his proposals in several works, which end up making criticisms and considerations about Criminal Law and the System. Criminal Justice, based on the panoptic model and the new forms of punishment in prison, involving the transition from the feudal model to the capitalist system of production. In this sense one can ask: what is the Foucaultian conception regarding the illegalities in this new punitive model? In the hypothesis to be developed, Foucault starts from a critique of the format of the illegality of goods and the illegality of rights, rethinking the judicial apparatus and its legal status which aims "not the equality of all before the law", but protection of ownership of goods and, consequently, the repression of popular illegalism; on the other hand, the permission to the practice of illicit by the holders of the productive means.

Keywords: Illegality, goods, law, capitalism.

\section{Considerações iniciais}

O francês Michel Foucault é uma pensador da Filosofia do Direito e como tal trata das mais variadas questões, no campo da Filosofia, da Psicologia e do Direito desenvolvendo sua perspectiva no campo do direito a partir de um ângulo diferenciado. Sua obra é importante a medida que compreende questões fenomênicas no universo jurídico, a partir de suas ideias. O pensamento de Foucault tem seu ápice nas décadas de 1960, 1970 e 1980, em que busca a compreensão das relações estruturais de poder e dominação, bem como, suas formas de manifestação no campo da sexualidade, da loucura, da linguagem e do direito.

O sistema panóptico de Jeremy Benthan forneceu o material para sua reflexão e suas obras. Foucault 
toma como ponto de partida para sua análise do Século XVII e XVIII, a experiência desse modelo prisional para estabelecer as categorias estruturais de seu pensamento. Esse fenômeno representou uma experiência nova, sob o ângulo da prisão, como modalidade única de punição, do ponto de vista da justiça criminal, com desdobramentos que moldaram as normas jurídicas estatais e a soberania estatal, em razão das consequencias desse modelo de prisão em todas as esferas da vida social, tais como, a educação, a família, nas fábricas, nos vizinhos, ou seja, na difusão das microfísicas do poder.

Dessa forma, a reflexão foucaultiana sobre as políticas das ilegalidades, as quais foram ao contrário do período feudal que tinha por exclusividade a utilização do espetáculo dos suplícios e do exercício da força bruta na punição ao corpo, baseada na vontade do soberano (monarca), para o autor acabam tendo uma mudança paradigmática; de tal modo que, com o desenvolvimento da sociedade capitalista e o estado como intermediário, surge a divisão de forma estruturada que corresponderia ao caráter de classes, dando origem a novas formas de ilícitos e um novo arranjo no sistema penitenciário, a partir das ideais de suavização e humanização das penas.

Sendo assim, o presente trabalho tem por objetivo analisar a transferência do elemento penitenciário para o aparato penal, para resolução de conflitos referentes ao ilegalismo popular/ classes sociais, e a proteção dos bens de propriedade no sistema capitalista, em sua riqueza e materialidade, indo além do simples choque com as leis e regulação do poder, mas com os bens em sua materialidade, o que demandará uma maior repressão à ilegalidade do "inimigo social", demarcando a existência um sistema penal justiça dual: de um lado a ilegalidade dos bens, mais acessível às classes populares e que sofrerá uma repressão violenta; de outro, a burguesia que se reservará a ilegalidade dos direitos, permitindo o desvio de seus próprios regramentos e leis.

O artigo é de natureza bibliográfica, será utilizado quanto ao método de abordagem no seu desenvolvimento o dedutivo, tendo pressuposto argumentos gerais (premissa maior) para argumentos particulares (premissa menor); enquanto o procedimento será analítico.

\section{0 poder disciplinar e a genealogia punitiva em Foucault}

Michel Foucault (1926-1984) foi um filosofo francês, que exerceu grande influência sobre os intelectuais contemporâneos, conhecido por sua posição contrária ao sistema prisional. Diplomou-se em Psicologia (1949) e Filosofia (1948), lecionando nas universidades francesas e obteve a cátedra com o tema História dos Sistemas de Pensamento no Collège de France. Dentre suas obras clássicas, estão a Doença Mental e Personalidade (1954), História da Loucura na Idade Média (1961), tese de doutorado na Sorbonne. Ainda, publicou o Nascimento da Clínica (1966), As Palavras e as Coisas e Arqueologia do Saber (1969), Vigiar e Punir o Nascimento da Prisão (1975) e a História da Sexualidade (1976).

A filosofia foucaultiana consubstanciada na obra Vigiar e Punir debruça sua análise sobre o sistema penal francês questionando o sistema prisional, em especial, a prisão, como modalidade única de punição, considerando como resultado do desenvolvimento de técnicas disciplinares, isto é, não em decorrência do resultado de uma evolução progressista das teorias jurídicas do século XVIII, eis que as técnicas de disciplina ocorriam no momento em que o poder monárquico absolutista era demasiadamente custoso e com pouca eficácia. A forma de exercício do poder tinha como objeto os corpos, na eficácia produtiva de seus movimentos, na normatização e na maximização de sua utilidade docilidade (YAZBEK, 2014, p. 24).

O formato do sistema prisional parte da premissa do modelo panóptico e arquitetônico de uma prisão ideal, do jurista e filósofo iluminista de Jeremy Bentham (1791), sendo utilizado como paradigma de 
Foucault para uma nova espécie de poder, denominada de poder disciplinar. A ilustração desse modelo prisional funciona como uma espécie de diagrama para uma maneira de concepção de poder, em sentido contrário, ao espetáculo dos suplícios na figura do monarca/soberano, mas a partir de uma nova espécie de poder, mecânica e anônima, portanto, mediante a internalização de um olhar vigilante, tornando os sujeitos visíveis e separados (OSKHALA, 2011, p. 73).

$\mathrm{Na}$ visão da autora, embora a narrativa provocativa afirmação de Foucault sobre panóptico, embora não sendo construído, os seus elementos caracterizam essa nova forma de poder disciplinar, a partir dos elementos contidos no projeto e na construção de muitas instituições e espaço da sociedade moderna, tais como, as fábricas, as prisões, as escolas, os hospitais. Na sociedade disciplinar o poder é exercido mediante uma forma de violência considerada difusa, porém de maneira anônima. Todavia, hoje, por exemplo, assume forma tecnológica mais moderna das câmeras, dos telefones monitorados, das tornozeleiras, sem modificar os princípios em relação ao modus operandi, os quais permanecem intactos.

$\mathrm{Na}$ visão de Foucault, a máquina panóptica para o encarceramento é essencial ao panoptismo como exercício do poder disciplinar no qual a vigilância regrada e permanente a qual constituirá o principio geral de uma anatomia política cujo escopo seria as relações de disciplina, isto é, a sociedade de espetáculos passará a ser de vigilância relacionada há uma tecnologia vigilante na distribuição da visibilidade do espaço, seu lugar efetivo de exercício. O arranjo panóptico de Bentham funcionaria como uma rede de dispositivos localizados em toda parte, ramificado em toda sociedade, de forma ininterrupta e generalizada, engendrando a base de uma sociedade constituída e verticalizada por mecanismos disciplinares ${ }^{1}$. Nesse sentido, segundo as lições de Mascaro (2007, pp. 161-162):

A partir da década de 1970, nas suas grandes obras que se aproximam imediatamente da questão do direito, como Vigiar e Punir e os textos de suas conferências no Rio de Janeiro que entre nós são conhecidos como A verdade e as formas jurídicas, Foucault já busca proceder a uma compreensão mais específica dos mecanismos do poder, espraiados no exemplo da loucura, da sexualidade, da criminalidade. Nesse profundo estudo a respeito dos mecanismos do poder, que não são aqueles tradicionalmente consideradospelo sociólogo, como Estado, o poder militar ou as instituições jurídicas, mas sim manifestações que se esparramam socialmente, Foucault chega a conceitos fundamentais e muito inovadores, como os relacionados aos poder normalizador, tratando, então das disciplinas, dispositivos e do biopoder. O poder não é uma manifestação institucional, formal, são biopoder, relacionada ao próprio domínio da vida.

De outro modo, haveria uma "relação binária" inicial na arquitetura do modelo panóptico: o poder visível e inverificável, em que o detento tenha a sensação de vigilância, pois essencial que saiba que está sendo vigiado; inverificável o detento deve ter conhecimento que esta sendo observado e que sempre po-

10 Panóptico de Bentham é a figura arquitetural dessa composição. 0 princípio é conhecido: na periferia uma construção em anel; no centro, uma torre; esta é vazada de largas janelas que se abrem sobre a face interna do anel; a construção periférica é dividida em celas, cada uma atravessando toda a espessura da construção; elas têm duas janelas, uma para o interior, correspondendo às janelas da torre; outra, que dá para o exterior, permite que a luz atravesse a cela de lado a lado. Basta então colocar um vigia na torre central, e em cada cela trancar um louco, um doente, um condenado, um operário ou um escolar. Pelo efeito da contraluz, pode-se perceber da torre, recortandose exatamente sobre a claridade, as pequenas silhuetas cativas nas celas da periferia. Tantas jaulas, tantos pequenos teatros, em que cada ator está sozinho, perfeitamente individualizado e constantemente visível. 0 dispositivo panóptico organiza unidades espaciais que permitem ver sem parar e reconhecer imediatamente. Em suma, o princípio da masmorra é invertido; ou antes, de suas três funções - trancar, privar de luz e esconder só se conserva a primeira e suprimem-se as outras duas. A plena luz e o olhar de um vigia captam melhor que a sombra, que finalmente protegia. A visibilidade é uma armadilha (FOUCAULT, 1999, p. 223). 
derá sê-lo, ou seja, esse modelo constitui em uma máquina de separar o "ver-ser" visto: no anel periférico, é plenamente visto, sem nunca visualizar; na torre do centro, ao contrário, tudo se vê, mas sem nunca ser visto.

Esses dois fatores acarretam na automatização e desindividualização do poder. A sua compreensão não será o individuo, mas na distribuição concertada (corpos, superfícies, das luzes e dos olhares), as quais a aparelhagem, em relação aos presos, busca assegurar a diferença, independente de quem exerça o poder central; qualquer individuo poderá operar a máquina (funcionando, na falta do diretor do cárcere, sua família, amigos, visitas, criados), pois se trata de uma máquina que a partir dos desejos mais heterógenos, fabrica efeitos homogêneos de poder, devendo o modelo ser compreendido de forma generalizada, como sendo uma relação de poder ramificada na vida dos homens (FOUCAULT, 1999, p. 225) 2 .

Embora na monarquia o corpo tenha sido associado ao poder disciplinar e a ordem social, em essência são um fenômeno novo no mundo moderno; ha outras formas de coerção física, ele não mutila o corpo do delinquente, mas vai se lapidando de maneira mais profunda e detalhada, de modo que os criminosos, gradativamente vão incorporando os objetivos do poder, que irão se tornar as regras básicas de seus objetivos e comportamentos; a disciplina do aprisionamento sujeitara não somente seu corpo, mas indo além fara o domínio e, amoldando a disciplina do cárcere sobre a própria alma do prisioneiro (OKSALA, 2011, p. 76).

No magistério do professor Marcos Duarte, em primeiro lugar, o adestramento colocaria o individuo em uma situação de inferioridade de seu superior (detentor do poder). Em segundo, a disciplina fábrica os indivíduos, moldando o sujeito à obediência cega. Em terceiro, se deve ao uso de instrumentos simples, desdobrando-se em três espécies disciplinares: o olhar hierárquico, a sanção normalizadora e o exame para se alcançar tamanho poder. O olhar teria a função sagaz, gelado, questionador para fazer o adulto parar e repensar seus atos e pensamentos. A sanção fomenta o medo efetivando a disciplina e o exame teria por função o controle dos resultados por quem detém o poder (DUARTE, 2014, p. 95).

Destarte, o panóptico não seria somente uma forma arquitetônica, mas, sobretudo, uma forma de governo e de exercício de poder disciplinar sobre o outro. A forma da prisão na qualidade de mecanismo fundamental essencial ao funcionamento da sociedade disciplinar precede a sua utilização sistemática das leis penais (o processo geral de disciplinarização já estava presente na sociedade do final do século XVIII). Assim, como bem observa Foucault (1999, p. 245), "os panoptismos foram, na genealogia da sociedade moderna, com a dominação de classe que a atravessa, a contrapartida política das normas jurídicas segundo as quais era redistribuído o poder".

A moderação e a proporcionalidade das penas, especialmente, acerca do modelo dos suplícios, já eram objetos de questionamentos e, por consequência, de contestação em toda parte na segunda metade do século XVIII, entre os filósofos, teóricos do direito, juristas, magistrados, parlamentares; entre os legisladores das assembleias, pugnavam pela aboliçãodetoda espécie de suplícios que revoltavam a humanidade. Exigia-se outro paradigmapunitivo, especialmente, em função da eliminação do confronto físico, direto e

\footnotetext{
2 No filme o sonho de Liberdade (1994), conta a história de Andy, um bancário bem sucedido que foi preso de forma injusta, acusado de matar esposa e o amante dela, passando a viver a vida na penitenciária aderindo aos costumes, valores e cultura do sistema penitenciário, tenta melhorar a vida na prisão e faz amizade com o veterano Red (Morgan Freeman), chefe do mercado negro local que almejava por muitos anos a liberdade. 0 personagem, após vinte anos na prisão retorna a sociedade para trabalhar em um supermercado; contudo, a institucionalização dentro da prisão, o levou a automatização e a disciplina que a todo o momento que precisava ir ao banheiro requeria licença a um dos seus chefes.
} 
frontal entre monarca e o condenado, ou seja, do supliciado e do carrasco. O questionamento foucaultiano tem como pressuposto de análise dois elementos estratégicos presentes na reivindicação de uma penalidade suavizada: medida e humanidade (FOUCAULT, 1999, pp. 94 - 95).

Essa necessidade de um castigo sem suplício é formulada primeiro como um grito do coração ou da natureza indignada: no pior dos assassinos, sua humanidade deve ser respeitada. No século XIX, em que esse homem, descoberto no criminoso, se tornará o alvo da intervenção penal, o objeto que ela pretende corrigir e transformar, o domínio de uma série de ciências e de práticas penitenciárias, criminológicas. O castigo corporal a exibição do corpo supliciado, o espetáculo do suplicio público passam a ser condenada em nome de certa tendência a humanização das penas. Para tanto, mister observar que:

Essa necessidade de um castigo sem suplício é formulada primeiro como um grito do coração ou da natureza indignada: no pior dos assassinos, uma coisa pelo menos deve ser respeitada quando punimos: sua "humanidade". Chegará o dia, no século XIX, em que esse "homem", descoberto no criminoso, se tornará o alvo da intervenção penal, o objeto que ela pretende corrigir e transformar, o domínio de uma série de ciências e de práticas estranhas "penitenciárias", "criminológicas". Mas, nessa época das Luzes, não é como tema de um saber positivo que o homem é posto como objeção contra a barbárie dos suplícios, mas como limite de direito, como fronteira legítima do poder de punir. Não o que ela tem de atingir se quiser modificá-lo, mas o que ela deve deixar intato para estar em condições de respeitá-lo. Noli me tangere. Marca o ponto de parada imposto à vingança do soberano. O "homem" que os reformadores puseram em destaque contra o despotismo do cadafalso é também um homemmedida: não das coisas, mas do poder. (FOUCAULT, 1999, p. 96).

Sobretudo, na França, o castigo corporal, a exibição do corpo suplicado, o espetáculo público do suplicio passaram a ser condenados, sob a égide de uma tendência a "humanista" das penas. O castigo do corpo enquanto regra do poder político, exigia sua modificação, a partir de uma suavidade da aplicação das sanções, cedendo lugar a uma economia calculada do poder de punir. Esse deslocamento no ponto de aplicação envolveria uma técnica de poder que difere dos sofrimentos do corpo/suplícios; ou seja, uma nova anatomia do poder político exsurge, sobre o espírito emum jogo de representações / sinais que circulam de maneira discreta, não mais o corpo, mas sobre a alma. (FOUCAULT, 1999, pp. 120 - 121).

Por intermédio da lente de Foucault, o rei detinha um papel fundamental, não sendo fruto de uma metáfora, mas da realidade política concreta, eis que sua presença era de vital importância para o funcionamento do sistema monárquico. Não será necessário ritual para restauração da sua integridade, mas serão aplicadas "receitas médicas" (controle dos contagiosos, exclusão dos delinquentes, eliminação dos doentes, sendo a técnica do suplicio substituída, por métodos assépticos, dentre eles, a criminologia, a eugenia, a exclusão dos degenerados). Assim, o poder não estaria presente no sistema político, narepública ou monarquia, mas a partir do controle corporal, ou seja, o poder penetra no corpo, encontra-se exposto no próprio corpo (FOUCAULT, 1979, p. 82).

Não podemos olvidar que o direito penal antigo desconhecia o cárcere, sendo a essa fase marcada, notadamente, e durante séculos, pelo fazer sentir a crueldade dos castigos e a vingança pública, como a interferência da forma direita pelo poder social no domínio repressivo, onde as penas eram intimidatórias. Embora a humanização do quartel do século XVIII, para que houvesse a "suavização" das sanções, provocada e difundida no século das luzes (Iluminismo), o Direito Penal passou por um estágio de transformações e investigações científicas, até chegar ao período contemporâneo de sua cientificidade, chamado de penitenciário.

Essa semiotécnica das punições, enquanto poder ideológico, na visão de Foucault, terá como foco 
elementar, o corpo novamente, como o ator principal. Essa nova anatomia política permitirá recruzar as duas linhas divergentes dos objetivos formadores no século XVIII: a rejeição do delinquente contra a natureza; por outro lado, a busca pelo controle da delinquência por uma anatomia contabilizada das puniçõesdo sistema penal. A nova técnica de punir da modernidade ilustrará a substituição da semiotécnicapunitiva corpo.

Os denominados novos saberes, como a psiquiatria e a psicologia, e nos personagens, como os peritos forenses, começam a tomar parte do sistema judicial carcerário ${ }^{3}$. O suplemento de poder, as formas excedentes de seu exercício, já não se manifesta no excesso da força física que o corpo (suplicado) com o monarca, mas no que Foucault denomina de elemento incorporal no qual é possível conhecer e manejar a substância e a dinâmica da criminalidade e, sobretudo sua periculosidade. Em outros termos, o objeto desse novo dispositivo punitivo já não é simplesmente o corpo dos indivíduos, mas sua vida, ou melhor, dizendo, seu corpo por intermédio da alma (CASTRO, 2015, p. 87).

Importante sublinhar que a análise genealógica das práticas punitivas tem o corpo supliciado como um objeto simbólico, dado como espetáculo, pois a execução pública é o centro da prática punitiva; mais o espetáculo desse corpo simboliza o poder real e monárquico, ligando o culpado diretamente ao crime, de modo que o espetáculo forma um cerimonial judiciário que tem por finalidade trazer à luz a verdade do delito. Portanto, o crime lesava a majestade o príncipe, sendo a liturgia da execução pública da punição a demonstração da vitória do poder soberano, a ofensa que lhe fora feita (YAZBEK, 2014, p. 109)

$\mathrm{Na}$ verdade, a passagem de uma criminalidade de sangue para uma criminalidade de fraude faz parte de todo um mecanismo complexo, onde figura o desenvolvimento da produção, o aumento das riquezas, uma valorização jurídica moral maior das relações de propriedade, métodos de vigilância mais rigorosos, um policiamento mais estreito da população, técnicas mais bem ajustadas de descoberta, de captura, de informação: o deslocamento das práticas ilegais é correlato de uma extensão e de um afinamento das práticas punitivas (FOUCAULT, 1999, p.98).

Isso significa um esforço para ajustar os mecanismos de poder que enquadram a existência dos indivíduos em sua harmonia, assim como, os instrumentos de vigiar o comportamento cotidiano das pessoas, sua identidade, atividade, gestos; significa outra política a respeito dessa multiplicidade de corpos e forças. Essa nova definição não acarreta na humanização dos condenados, mas numa justiça euma vigilância penal mais alerta ao corpo social. De acordo com um processo circular quando se eleva o limiar da passagem para os crimes violentos, também aumentam a intolerância aos delitos econômicos, os controles sociais ficam mais rígidos e o aumento das intervenções penais.

O verdadeiro objetivo da reforma, e isso desde suas formulações mais gerais, não é tanto fundar um novo direito de punir a partir de princípios mais eqüitativos; mas estabelecer uma nova "economia" do poder de castigar, assegurar uma melhor distribuição dele, fazer com que não fique concentrado demais em alguns pontos privilegiados, nem partilhado demais entre instâncias que se opõem; que seja repartido em circuitos homogêneos que possam ser exercidos em toda parte, de maneira contínua e até o mais fino grão do corpo social. A reforma do direito criminal deve ser lida como uma estratégia para

\footnotetext{
3 Para Foucault, existem dois elementos característicos e primordiais do aparelho disciplinar, não desconsiderando outros fatores inerentes a arqueologia do pensamento do autor, mas seriam, basicamente 1) a distribuição dos corpos em um espaço visível; 2) consequentemente, a partir da vigilância que permite o controle da atividade individual, para que assim possa extrair o máximo de utilidade produtiva. Nesse novo formato de tecnologia política, seria conveniente a partir da nova situação econômico social da Europa, no fim do século XVIII e da prisão enquanto modelo punitivo da reclusão prisional tendo na vigilância, a norma e o exame os ingredientes necessários para a configuração básica do poder disciplinar (YAZBEK, 2014, p. 116).
} 
o remanejamento do poder de punir, de acordo com modalidades que o tornam mais regular, mais eficaz, mais constante e mais bem detalhado em seus efeitos; enfim, que aumentem os efeitos diminuindo o custo econômico (ou seja, dissociando-o do sistema da propriedade, das compras e vendas, da venalidade tanto dos ofícios quanto das próprias decisões) e seu custo político (dissociando-o do arbitrário do poder monárquico). A nova teoria jurídica da penalidade engloba na realidade uma nova "economia política" do poder de punir. (FOUCAULT, 1999, p. 101)

Por outro lado, a reforma penal, não pode ser compreendida fora sua totalidade, contextualizada somente por critérios eminentemente humanizadores da pena, ou estritamente jurídicos, mas se levando em consideração os fatores políticos, econômicos e sociais no período da formação da sociedade industrial. A passagem dos suplícios corporais até a adoção do modelo de reclusão carcerária, como alicerce de todo sistema punitivo do Estado moderno capitalista tem fundamento a sanção penal como um instrumento jurídico/político e de controle social, evidenciando a cumplicidade estrutural e a relação entre Estado e Direito.

Embora tenha havido criticas ao método penal - corporal (vingança), estabelece-se um paradoxo: criticas por parte dos reformadores, desconsiderado aspectos políticos e econômicos na reforma do direito penal, mas buscando justificativas legitimadoras para construção de um novo modelo punitivo politicamente menos desgastante e ideologicamente mais útil para o Estado Moderno capitalista. A humanização da punição, portanto, deve ser considerada apenas com um dos argumentos que sustentaram a reformulação desse sistema, e por sua vez, de importância periférico/secundária (CHIES, 1997, p. 31).

Sendo assim,ocorre a junção entre essas esferas de poder: o poder constituinte que faz a própria a lei e o judiciário que formula uma sentença aplicando a lei, em razão da existência de privilégios nos tribunais: processos, litigantes, crimes que são privilegiados, estão fora do direito comum, desnaturando, o princípio de uma justiça penal pelas múltiplas instâncias encarregadas de realizá-la, desconstituindo a pirâmide única e contínua, por uma rede de regulamentos, instituições e aparelhos dotados não de soberania, mas estabelecendo relações de dominação dos condenados. Na obra Microfísica do Poder, esclarece Foucault:

Um princípio geral no que diz respeito às relações entre direito e poder: parece-me que nas sociedades ocidentais, desde a Idade Média, a elaboração do pensamento jurídico se fez essencialmente em torno do poder real. É a pedido do poder real, em seu proveito e para servir-lhe de instrumento ou justificação que o edifício jurídico das nossas sociedades foi elaborado. No Ocidente, o direito é encomendado pelo rei. Todos conhecem o papel famoso, célebre e sempre lembrado dos juristas na organização do poder real. E preciso não esquecer que a reativação do Direito Romano no século XII foi o grande fenômeno em torno e a partir de que foi reconstituído o edifício jurídico que se desagregou depois da queda do Império Romano. Esta ressurreição do Direito Romano foi efetivamente um dos instrumentos técnicos e constitutivos do poder monárquico autoritário, administrativo e finalmente absolutista. Quando, nos séculos subsequentes, esse edifício jurídico escapar ao controle real, mais precisamente quando se abater sobre ele, o que se questionará serão os limites deste poder e seus privilégios. Em outras palavras, o personagem central de todo o edifício jurídico ocidental é o rei. E essencialmente do rei, dos seus direitos, do seu poder e de seus limites eventuais, que se trata na organização geral do sistema jurídico ocidental. Que os juristas tenham sido servidores do rei ou seus adversários é sempre do poder real que se fala nesses grandes edifícios do pensamento e do saber jurídico (1979, p. 101).

Nesse sentido, a elucidação com que esse poder acaba sendo formado a partir da blindagem jurídica exercida pelo poder real (a ideia de soberania estava encarnada no corpo vivo do monarca), adaptada ao seu direito fundamental e poder absoluto. Por outro lado, o autor salienta a necessidade de limitação do 
poder soberano e quais as regras jurídicas deveria submeter-se para conservação de sua legitimidade. A teoria do direito, da Idade Média, terá o papel essencial de fixar a legitimidade do poder, tendo como problema central a soberania.

Michael Foucaultchama a atenção para cinco precauções que configuram uma síntese a respeito do poder, do Estado e do Direito; primeiro, ao postular uma compreensão da microfísica do poder com a finalidade de inverter o itinerário da análise do discurso jurídico, fazendo busca o fato da dominação no seu intimo/brutalidade, o direitonão apenas como instrumento oriundo dessa dominação, mas até que ponto do direito,no conjunto de aparelhos, instituições e regulamentos teria aplicação prática háum grupo especifico e amplas formas de exercício, independente da questão jurídica.

Para Foucault (1979, p. 102), “o problema é evitar a questão central para o direito da soberania e da obediência dos indivíduos que lhe são submetidos e fazer aparecer em seu lugar o problema da dominação e da sujeição". Portanto, não o rei em sua posição central, mas os súditos em suas relações recíprocas: não a soberania em seu edifício único, mas as múltiplas sujeições existentes no interior do corpo social. Os sistemas do direito funcionariam como canais permanentes de relações de dominação, assim como, técnicas de sujeições polimorfas,enquanto um procedimento de sujeição, que ele desencadeia, e não como uma legitimidade a ser estabelecida. De tal modo que,

Em primeiro lugar: não se trata de analisar as formas regulamentares e legítimas do poder em seu centro, no que possam ser seus mecanismos gerais e seus efeitos constantes. Trata-se, ao contrário, de captar o poder em suas extremidades, em suas últimas ramificações, lá onde ele se torna capilar; captar o poder nas suas formas e instituições mais regionais e locais, principalmente no ponto em que, ultrapassando as regras de direito que o organizam e delimitam, ele se prolonga, penetra em instituições, corporifica-se em técnicas e se mune de instrumentos de intervenção material, eventualmente violento. Exemplificando: em vez de tentar saber onde e como o direito de punir se fundamenta na soberania tal como esta é apresentada pela teoria do direito monárquico ou do direito democrático, procurei examinar como a punição e o poder de punir materializavam-se em instituições locais, regionais e materiais, quer se trate do suplício ou do encarceramento, no âmbito ao mesmo tempo institucional, físico, regulamentar e violento dos aparelhos de punição. (FOUCALT, 1979, p. 102)

Nesse aspecto, seria necessário á percepção do poder na extremidade, na periferia, e não pela via jurídicade seu exercício, mas a partir da análise do poder em seu nível do processo de sujeição e constituiçãoaos súditos (multiplicidade dos corpos, das forças, das energias, das matérias, dos desejos, dos pensamentos, dos gestos). Ao contrário dos juristas que buscam na multiplicidade dos indivíduos/ vontades em um corpo único/vontade única, movida por uma alma (a soberania), baseada em Hobbes (Leviatã), mas tendo como premissaos corpos periféricos, múltiplos, constituídos como sujeitos pelos efeitos de poderfísico, regulamentar e violento dos aparelhos punitivos (FOUCALT, 1979, p. 102).

$\mathrm{Na}$ terceira precaução Foucault dirá que o poder não é um fenômeno binário, em que os indivíduos seriam totais, submetidos uns sobre os outros ou, por uma classe sobre a outra. O poder deverá ser analisado em seu movimentocircular, funcionando em cadeia, não sendo propriedade de alguns ou apropriado como uma riqueza, mas sendo exercido como centros de transmissão (rede), não se aplicando aos indivíduos enquanto átomo primitivo, entrelaçando-os ou destruindo; o que se faz dos gestos, do corpo, dos desejos seria um dos primeiros efeitos do poder (efeito e transmissão), estaria nas cadeias das relações opressivas, nas estruturas sociais que se verifica o poder (FOUCAULT, 1979, p. 103).

Em relação à quarta precaução: o importante não é fazer uma espécie de dedução do poder,partindo do centro prolonga até a periferia, mas em que medida se reproduz, até chegar aos elementos 
moleculares da sociedade. Deve-se fazer uma análise ascendente (poder), tem como premissa os mecanismos infinitesimais que têm uma história, caminho, técnicas e tática, de modo há examinar como estes mecanismos foram e ainda são investidos, por mecanismos gerais de tecnologia de poder levando em consideração a maneira como os fenômenos, as técnicas e os procedimentos de poder atuam, se expandem e modificam. De tal modo que,

A partir do século XIX, novamente devido a determinadas transformações, um lucro político, eventualmente alguma utilidade econômica, que consolidaram o sistema e fizeram-no funcionar em conjunto. A burguesia não se interessa pelos loucos, mas pelo poder; não se interessa pela sexualidade infantil mas pelo sistema de poder que a controla; a burguesia não se importa absolutamente com os delinquentes nem com sua punição ou reinserção social, que não têm muita importância do ponto de vista econômico, mas se interessa pelo conjunto de mecanismos que controlam, seguem, punem e reformam o delinquentequanto aos seus mecanismos de exclusão da loucura e de vigilância da sexualidade infantil evidenciaram, a partir de um dadocontexto,por motivos de lucro econômico e utilidade política, tornando-se, naturalmente colonizados e sustentados por mecanismos globais do sistema estatal focalizando estas técnicas de poder e os lucros econômicos, como compreensão da efetivação desses mecanismos em seu e como parte conjunto.

Desse modo, na visão de Foucault, a classe burguesa não precisou excluir os loucos do processo de vigilância, ou ainda, da proibição quanto à masturbação infantil, cujo interesse era centralizado na técnica e exclusão enquanto procedimento. Seriam os mecanismos de exclusão, os aparelhos de vigilância, a medicalização da sexualidade, da loucura, da delinquência, funcionando como uma micro - mecânica do poder que representou um interesse ao modelo burguês.

A quinta precaução metodológica cuida da possibilidade das grandes máquinas de poder e seu acompanhamento pelas produções ideológicas. Houve uma tendência, por exemplo, na criação de uma ideologia da educação; uma ideologia do poder monárquico, uma ideologia da democracia parlamentar; contudo, a base não estaria fixada somente pelo critério da ideologia. Além disso, são instrumentos reais de formação e de acumulação do saber, métodos de observação, técnicas de registro, procedimentos de inquérito e pesquisa, aparelhos de verificação em que o poder exerce nestes mecanismos, sendo obrigado a formar, organizar e circular os aparelhos de saber que não são construções puramente ideológicas.

Sendo assim, durante todo o século XVIII, no ambito interno e externo do sistema judiciário, na prática penal e na crítica as instituições, a ideia seria uma estratégia para o exercício do poder punitivo. E a "reforma" hipotética, formulada no ambito das teorias de direito, é a retomada política/filosófica dessa estratégia, com o escopo de fazer da punição e da repressão das ilegalidades uma função regular, coextensiva à sociedade, a partir da ideia de punir menos, mas punir melhor; severamente, mas de forma mitigada, punir de forma universal, verticalizada e assimétrica com inserção profunda no corpo e no espirito social.

\section{A ilegalidade de bens e direito no sistema capitalista}

Para começar, precisamos determinar melhor a peculiaridade do Capitalismo como conjunto de comportamentos individuais e coletivos, atinentes à produção, distribuição e consumo dos bens. Embora esta peculiaridade tenha sido e continue sendo objeto de controvérsia histórica, cultural e sociológica podemos elencar algumas características que distinguem o Capitalismo dos outros modos históricos de produção:

a) propriedade privada dos meios de produção, para cuja ativação é necessária a presença do traba- 
lho assalariado formalmente livre; b) sistema de mercado, baseado na iniciativa e na empresa privada, não necessariamente pessoal; c) processos de racionalização dos meios e métodos diretos e indiretos para a valorização do capital e a exploração das oportunidades de mercado para efeito de lucro. Ao lado da racionalização técnico-produtiva, administrativa e científica promovida diretamente pelo capital, está em ação uma racionalização na inteira "conduta de vida" individual e coletiva. Esta racionalização ou modernização política culmina na formação do sistema político liberal, que historicamente coexiste com o Capitalismo (BOBBIO, 1998, p. 152)

Marx e Engels mencionam o surgimento da burguesia, iniciando pela Idade Média, de onde teriam se desenvolvido os primeiros elementos. Em seguida, citam a descoberta da América e a circunavegação da África, como novos campos de ação para a classe burguesa que se encontrava em processo embrionário (colonização, comércio com as colônias, aumento de volume de mercadorias em geral), tendo em razão disso desenvolvido o elemento revolucionário no âmbito do declínio da sociedade feudalista. (BOGO, 2005). Sendo assim, os autores colocam que o surgimento da burguesia moderna é produto de um longo processo, moldado por uma série de transformações nas formas de produção e circulação.

Os Estados se apoiam em redes de repressão já existentes, mas reconstroem-nas. A unidade de um povo passa a ser institucionalizada com o monopólio estatal do controle dos comportamentos desviantes. Assim, há uma passagem qualitativa entre as velhas repressões religiosas e culturais à mulher do tempo feudal e a repressão jurídica que o Estado assegura em favor do poder paterno. Mantendo, excluindo ou alterando repressões, o Estado se impõe como a forma necessária de unidade entre opostos, repressores e reprimidos, tal qual o faz, por sua vez, na circulação mercantil, como forma política e jurídica necessária da transação entre os sujeitos de direito no sistema capitalista (MASCARO, 2013, p.89).

Por outro lado, temos na visão de Foucault dois vetores principais: uma critica a justiça penal de caráter irregular, isto é, atravessada por uma multiplicidade de instâncias cujo poder de decisão fragmentava-se em uma justiça dos senhores, uma justiça do rei, uma justiça administrativa e policial com poderes excessivos em instâncias inferiores, objeto de critica dos reformadores. Por sua vez, o desenvolvimento da sociedade capitalista, da edificação de uma política de ilegalidades que, ao mesmo tempo, há necessidade de reformulação do sistema penal cuja tecnologia não realize a supressão das ilegalidades, mas sua gestão e diferenciação (YAZBEK, 2014, p. 112). Com sapiência ensina Foucault.

É, portanto necessário controlar e codificar todas essas práticas ilícitas, definir as infrações punir com segurança, essa massa de irregularidades toleradas e sancionadas de maneira descontínua com ostentação; o que é infração intolerável e o castigo. Com as novas formas de acumulação de capital, de relações de produção e de estatuto jurídico da propriedade, todas as práticas populares que se classificavam, seja numa forma silenciosa, cotidiana, tolerada, seja numa forma violenta, na ilegalidade dos direitos, são desviadas à força para a ilegalidade dos bens. O roubo tende a tornar-se a primeira das grandes escapatórias à legalidade, nesse movimento, dasociedade da apropriação jurídico-política a uma sociedade da apropriação dos meios e produtos do trabalho; em outras palavras, vale dizer: a economia das ilegalidades se reestruturou com o desenvolvimento da sociedade capitalista. A ilegalidade dos bens foi separada da ilegalidade dos direitos (1999, p. 107).

Essa divisão sob o prisma foucaultiano corresponde a uma oposição de classes, pois, de um lado, os setores populares estarão acessíveis há um modelo de ilegalidade, qual seja a ilegalidade dos bens, que consiste na transferência violenta das propriedades; de outro modo, a burguesia se reservará a ilegalidade dos direitos, que permitira a possibilidade de desvio de suas próprias regras, leis, normas, regulamentos fazendocom que o funcionamento dacirculação econômica, em sua completude, se desenvolvida as mar- 
gens da legislação vigente, contida em seus silêncios, ou por intermédio de uma tolerância de fato.

Nesse aspecto, as redistribuições das ilegalidades se traduzirão por uma especialidade dos circuitos judiciários, num processo divisionário das ilegalidades para os bens e outro formato de ilegalidades para os direitos: em caso de roubo, tribunais ordinários e os castigos ilegalidade de bens; por outro lado, fraudes, evasões fiscais, operações comerciais irregulares, jurisdições especiais com transações, acomodações, multas atenuadas, configurando a ilegalidade de direitos reservada estritamente a própria classe burguesa. Simultaneamente, essa separação concretiza há necessidade da vigilância a ser feita sobre a ilegalidade dos bens (FOUCAULT, 1999, p. 107). Foucault esclarece que:

O crescimento e a instalação do modo de produção capitalista haviam provocado algumas crises políticas, a vigilância da plebe, embora sua incerteza em relação à utilização do termo, a qualse desejava proletarizar e a criação do novo aparato de repressão. Os movimentos de "sedição popular" tiveram como resposta uma nova sistemática repressiva por meio do sistema judicial/penitenciário, com a finalidade de contenção, em particular do ilegalismo popular, que até o final do século XVIII, era compatível com a ordem burguesa, funcionando como uma engrenagem do desenvolvimento econômico e da economia capitalista; contudo, passou a ser incompatível com a nova ordem (FOUCAULT, 2015, p. 130).

A importância dessa forma de ilegalidade, na visão foucaltiana, dar-se-á, dentre outros motivos, em razão do ilegalismo popular ser funcional, pois sua contribuição para a redução do lucro do capital em processo de industrialização, surgindo uma nova relação lucrativa própria do capitalismo, de não enfrentamento ao lucro comercial, cuja cobrança por parte do sistema feudal, tanto a direta do senhor quanto a cobrança estatal e, portanto, indireta, a toda uma série de cobranças feitas por meio de diretos e multas. Não era um ataque a propriedade material, mas um ataque ao direito, cuja fraude antifeudal servia a classe burguesa na luta por uma nova legalidade.

Para compreensão dessa ideia do ilegalismo popular, Foucault, exemplifica, a partir da profissão dos tecelões que adentrou rapidamente no ambito do sistema capitalista, que no século XVIII, era exercida no "limítrofe" entre a cidade e o campo. Seus regulamentos emanavam de um controlador geral de finanças, organizador da profissão (regulamento datado de 1748). Eram fabricadores de tecidos e poderiam comercializar, distribuir e exportar seus produtos, sendo controlados por ordenanças (cumprimento, qualidade, marca própria, registro em agencia), as quais tinhas regras tanto corporativas como restritivas, cuja fiscalização cabia a algumas pessoas que recebiam remuneração e ficam com metade dos produtos das multas, assim como, outras operações (operações, medida).

Para não ser submetidos a coerções, estabeleceu-se uma ilegalidade bilateral. O mercador (comercializador), e o tecelão (fabricante), estabeleciam uma relação direta, esquivando-se dos regulamentos, ao firmarem contratos antecipados, fora do mercado oficial, estabelecendo relações mercantis e comerciais; o comerciante adiantava pagamento ao tecelão, que adquiria novos instrumentos de produção. Desse modo, aos poucos, o modo de produção capitalista, inseriu-se num sistema artesanal próprio, em função dessa dupla ilegalidade (FOUCAULT, 2015).

Num segundo momento, havia o ilegalismo sistemático, cuja junção ocorria entre o ilegalismo popular com o ilegalismo dos negócios e privilegiados, imunes a lei, por estatuto ou exceção. Nesse interim havia relações antagônicas; o popular diminuía a renda (direta) e a arrecadação do Estado (indireta). Todavia, o ilegalismo burguês beneficiava-se, em regra, dos privilégios dos grandes proprietários/nobreza (isenção de impostos, pensões), sendo preciso evitar os desvios excessivos dos direitos no nível das receitas do Estado. 
Em terceiro, esse ilegalismo era politico/econômico; a relação de mercado estabelecida pela lei, não atacava a operação de poder, numa posição paradoxal da burguesia a qual apoiava as lutas antilegais, desde que não se sujeita a crime do direito comum (banditismo) ou a forma política (diligencias de impostos). Em quarto lugar, esse ilegalismo era oscilante, num jogo entre o ilegalismo popular e a lei (espécie de estratégia de jogo), em razão do conflito de dupla face; as classes populares percebiam a exploração burguesa e recorriamà proteção dos fiadores da legalidade (poder régio).

Porém, quando a burguesia recorria à ilegalidade, ao aparato judiciário, sem a presença das camadas populares. Assim, havia um antagonismo e desequilíbrio nas formas jurídicas, fruto de quatro espécies de ilegalismo, confrontantes entre si: popular, comercial, privilegiado e de poder (intendentes, subdelegados, tenentes de polícia). Esta compreensão tem condição à existência da lei com pressuposto de seu funcionamento. Assim, vale ressaltar as lições de Michel Foucault:

[...] o elo crescente entre a justiça e a força das armas. Não se pode impô-la senão por uma coerção armada: só onde o suserano é militarmente bastante forte para impor a sua "paz", pode haver extração fiscal e jurídica. Tendo-se tornado fontes de rendimento, as justiças seguiram o movimento de divisão das propriedades privadas. Mas, apoiadas na força das armas, seguiram a sua concentração progressiva. Duplo movimento que conduziu ao resultado clássico: quando no século XIV o feudalismo teve que enfrentar as grandes revoltas camponesas e urbanas, ele procurou apoio em um poder, em um exército, em um sistema fiscal centralizados; e, ao mesmo tempo, apareceram, com o Parlamento, os procuradores do rei, as diligências judiciárias, a legislação contra os mendigos, vagabundos ociosos e, dentro em pouco, os primeiros rudimentos de polícia, uma justiça centralizada: o embrião de um aparelho de Estado judiciário que cobria, reduplicava e controlava as justiças feudais com o seu sistema fiscal, mas que lhes permitia funcionar. Assim apareceu uma ordem judiciária que se apresentou como a expressão do poder público: árbitro ao mesmo tempo neutro e autoritário, encarregado de resolver justamente os litígios e de assegurar autoritariamente a ordem pública. Foi sobre este pano de fundo de guerra social, de extração fiscal e de concentração das forças armadas que se estabeleceu o aparelho judiciário (1979, p. 25).

A partir daí é possível delimitar a problemática: no fim do século XVIII, esses aparatos administrativos, policiais, de vigilância extrajudiciária funcionavam não como representantes da legalidade, mas como instância de arbitragem da ilegalidade, transformado pela burguesia em aparato, misturado ao sistema geral de ilegalismos, "engolfado" pela burguesia (na tomada de poder), para aplicação da sua "legalidade judiciária”, encarregado precisamente de livrá-la do ilegalismo popular (FOUCAULT, 2015, p. 135). Assim, o elemento penitenciário, segundo o autor, funcionava na rede da ilegalidade, será assumido e integrado no sistema de justiça, quando precisamente a burguesia já não poder tolerar o ilegalismo popular, como, por exemplo, do tecelão e dos operários portuários

Com a instalação da base da economia capitalista, esses estratos populares que em conjunto com os fiscais da alfândega, eram cúmplices, acabam se deslocando do artesanato para o salariado, da fraude ao roubo, fazendo as regras, por estatuto, burlando a lei, fruto da transferência da técnica e a formas de ilegalismo para a propriedade burguesa, a cumplicidade não era mais conveniente, sendo necessária a repressão por parte de um sistema penitenciário condensado e remodelado como instrumento político de controle e manutenção das relações de produção e a teoria do delinquente considerado como inimigo social, ao contrário do sistema feudal (inimigo público/suplício), e o trabalho no âmbito do sistema prisional.

Portanto, o sistema penal e penitenciário, em seu funcionamento e organização, ocasionaram a clivagem entre as duas justiças, para instauração, em especial, no campo penal. Com a proletarização da 
"plebe", ocorreu a transferência sobre a propriedade do setor burguês, das técnicas e, por conseqüência, as formas de ilegalismos criadas. De tal modo, quando a classe burguesa precisou criar mecanismos para ruptura do ilegalismo popular, tais como, códigos, prisões, colônias, exército, policia que separassem o delinqüente e o não delinqüente, a ilegalidade econômico política isentou-se de punição e não submetida ao direito penal comum, ao contrário dos inimigos populares (operário), o qual se confrontava com os bens de propriedade da classe burguesa em sua materialidade (FOUCAULT, 2015, p. 137).

Sendo assim, a nova legislação penal, em regra, se caracterizaria pela suavização e na humanização das penas; por outro lado, buscava estabelecer um consenso acerca do poder de punir, alicerçada basicamente por uma profunda alteração na economia tradicional das ilegalidades e uma rigorosa coerção para manter seu novo ajustamento gerenciador e tolerante. A partir da regra da especificação ideal fica claro, que essa semiótica penal deverá recobrir a totalidade do campo das ilegalidades, pois todas as infrações têm que ser reunidas, classificadas e controladas (FOUCAULT, 1999, p. 109).

Até finais do século XVIII se põe em marcha um amplo movimento de reformas em torno dos princípios e das técnicas do castigo. E a época dos grandes reformadores: Becarria, Servan, Dupaty, Duport, Pastoret, cuja estratégia geral desse movimento foi lograr maior regularidade e eficácia no castigo, fazendo com menor custo politico e econômico. Por um lado, a prática de suplícios questionada desde algumas décadas. O povo, de fato, ás vezes celebrava a resistência e a coragem dos condenados ou se sublevava contra a brutalidade de um poder do qual também ele era ou poderia ser vítima. De outro modo, com as formas do capitalismo nascente na sociedade burguesa, os delitos contra a propriedade e, sobretudo, as novas formas de fraude começaram a ter mais importância que os delitos de sangue (CASTRO, 2015, p. 88).

Nesta perspectiva, o poder capilar, descentralizado, fluído, amplamente disseminado nas instituições sociais, na família, na escola, nos meios de comunicação, nos mecanismos de consumo, na clínica, na fábrica, se anela aos instrumentos jurídicos repressores para servir ao "amoldamento" ou à "assujeitação" dos indivíduos a modelos confortáveis a práticas dominadoras e disciplinadoras. De fato, direito e poder, nas sociedades modernas, se constituem a partir de uma importante vinculação recíproca (BITTAR; ALMEIDA, 2005, p. 518).

De um lócus muito especial, a partir do foco teórico da investigação arqueológica de Michel Foucault, é possível, em nível crítico, considerar uma fecunda discussão de como as práticas jurídicas servem como mecanismo instrumental de "normalização" de comportamentos sociais, unindo-se a outras formas não jurídicas de instrumentação das forças normalizadoras da sociedade disciplinar. É esta a revelação trazida pela filosofia foucaultiana, ao adentrar nos arcanos dos processos formadores da sociedade moderna, aquela que prolonga seus efeitos sobre os modos de vida e de comportamento atuais.

Portanto, será necessário um código jurídico, exaustivo e explicito para cada tipo de infração penal, em que a impunidade não pode se precipitar na omissão da lei, que rigorosamente defina os crimes, fixando suas penas. Para que esse imperativo tenha funcionamento, o castigo/pena não terá a mesma força ao corpo social; à nocividade de um delito/castigo será em conformidade com o status social do infrator, para a nova economia política do poder de punir do Estado Moderno e do sistema capitalista, dando um novo invólucro necessário às ilegalidades, conforme as classes sociais, o que, por conseqüência, também terá reflexos no âmbito do sistema prisional, o qual não efetuará punições e encarceramentos a classe burguesa. 


\section{Conclusão}

Na obra Vigiar e Punir, no que se refere às práticas e ao Suplício como o método da pena evoluiu até o modelo prisional baseado no panóptico. O tema da disciplina enquanto parte da esfera do poder através das normas estatais, porém, a disciplina, apesar de não ser visualizada concretamente atinge o indivíduo no seu subjetivo (alma), pois controlam seus corpos e gestos através de mecanismos variados, fazendo do indivíduo um ser dócil e adestrado, através da vigilância hierárquica, das sanções normalizadoras e do exame.

A importância do pensamento de Foucault para a filosofia do direito é pela sua compreensão fenomênica do poder, do Estado, das instituições e do direito conexo aos fenômenos resultantes da disciplina e, portanto, como todo esse conjunto de fenômenos não pode ser analisado apenas como dados formais. Para o direito, a visão de Foucault é crítica, não se vislumbrando o fenômeno jurídico, a partir da relação norma-sujeito, sendo nas estruturas de poder a constituição do sujeito, permeando, o próprio Estado e as normas jurídicas, aonde se pode localizar o direito positivo estatal nas esferas denominadas de Microfísicas do Poder.

Ele descentraliza o poder, destituindo as instituições centrais como hierarquicamente superiores deste fenômeno trazendo para as periferias. Sob o prisma a uma oposição de classes (setores populares, especialmente os operários) a ilegalidade dos bens, que consiste na transferência da propriedade, sofrendo uma punição de forma violenta pelo aparato punitivo e judiciário; de outro, a burguesia se reservará a ilegalidade dos direitos, que permitira o desvio de seus regulamentos fazendo com que o sistema econômico capitalista se desenvolva as margens da legislação e sem qualquer estabelecimento de sanções do sistema de justiça criminal (códigos, prisões, colônias, exército, policia).

\section{Referências}

BITTAR, Eduardo, ALMEIDA, Guilherme de Assis. Curso de Filosofia do Direito. São Paulo Atlas 2004.

BOGO, Ademar (Org.). Teoria da Organização Política: escritos de Engels, Marx, Lênin, Rosa, Mao - São Paulo: Expressão Popular, 2005.

BOBBIO, Norberto. Dicionário de política. Brasília: Editora Universidade de Brasília, 1998.

CASTRO, Edgar. Introdução a Foucault. Belo Horizonte: Editora Autêntica, 2015.

CHIES, Luiz Antônio Bogo. Prisão e Estado: A função ideológica da privação da liberdade. Educat, 1997.

DUARTE, Marcos. Breve Ensaio sobre o Nascimento da BioPolítica de Foucault: São Paulo, Editora Max Limonad, 2014

FOUCAULT, Michel. A Sociedade Punitiva. Tradução Ivoni Benedetti. São Paulo: Martins Fontes, 2015.

.Vigiar e punir: nascimento da prisão; tradução de Raquel Ramalhete. Petrópolis, Vozes, 1999.

. Microfísica do poder. Tradução de Roberto Machado. Rio de Janeiro: Edições Graal, 1979.

MASCARO, Alysson Leandro. Estado e Forma Política. Editora Boitempo: São Paulo, 2013. 
. Filosofia do Direito - 2. Ed. - São Paulo: Atlas, 2012.

.Lições de Sociologia do Direito - São Paulo: QuartierLatin, 2007.

OKSALA, Johanna. Como Ler Foucault. Tradução. Rio de Janeiro: Editora Zahar, 2011.

YAZBEK. André Constantino. 10 Lições de Foucault. Vozes: Rio de Janeiro, 2014.

Artigo recebido em: 12 de dezembro de 2019

Artigo aceito em: 27 de dezembro de 2019 